\title{
Microbial Efficiency of Air Conditioners and other Ventilation Devices for Enhancing Future Air Quality
}

\author{
M.N. Modebelu \\ Department of Agricultural and Science Education \\ Michael Okpara University of Agriculture, Umudike, Abia State, Nigeria \\ A. F. Modebelu \\ Department of Applied Microbiology and Brewing \\ Nnamdi Azikiwe University, Awka-Anambra State, Nigeria
}

Doi:10.5901/ajis.2012.v2n5p163

Abstract

Microbial efficiency of air-conditioners $(A / C s)$ and other ventilation devices like electric fans (EFs) and open doors/windows $(D W s)$, as means of enhancing future air quality was studied in Anambra state. Four hundred (400ml) of water samples dripping from A/Cs discharge nozzles were collected from 45banks, 61 hospitals and 44 hotels (total of 150 samples) selected from the 21 local government areas( LGAs) in the state, using proportionate random sampling technique. A/Cs vents, EFs blades and DWs surfaces in the selected institutions were also swabbed and examined. Some of the findings are as follows; One hundred and twenty-six (126) bacterial isolates were recovered from the 150 water samples collected from $A / C_{s}$ in the various establishments. Bacterial isolates from banks were 36(28.6\%), hospitals 54(36.0\%) and 33(22.0\%) from hotels. There were 4 predominant and frequently isolated bacterial species, which when pooled in the institutions recorded; Micrococcus luteus 50(39.7\%), Arthrobacter globiformis 36(28.6\%), Staphylococcus epidemidis 30(23.8\%) and Staphylococcus aureus $10(7.9 \%)$. Statistical analysis of the results showed that calc. F value of 0.10 was $<3.11$ critical value p $0.05 \mathrm{df} 2 / 60$. The null hypothesis of no significant statistical differenc in bacterial isolates from A/Cs water samples was accepted. Eighty-eight bacterial isolates from 135 swab samples from A/Cs vents, EFs blades and DWs surfaces in banks using the various devices showed that they had 36(26.7\%), 28(20.7\%) and 24(17.8\%) bacterial isolates respectively. Statistical analysis of the results indicated that calc. F value 11.57 was $>3.11$ critical value $p 0.05 \mathrm{df} 2 / 60$. The alternative hypothesis of, there was significant statistical difference in bacterial isolates from surfaces of $A / C s$, EFs and DWs in banks was accepted. Ability of the isolates to access and inhabit ventilation devices, call for alternative materials for their construction by engineers, to make them un-habitable by microbes. This will guarantee their safe use as means of achieving future air quality globally.

Keywords; Air quality, Ventilation devices, Microbial isolates, Air-conditioners, Institutions.

\section{Introduction}

Air quality is a measure of the purity of air around and within structures and vehicles, as it affects the health and comfort of the occupants. Indoor air quality (IAQ) can be affected by gases [including] carbon monoxide, radon, volatile organic compounds, particulates, microbial contaminants [moulds, bacteria] or any mass or energy stressor that can induce adverse health conditions (Wikipedia, 2012). Source control filtration and the use of ventilation, to dilute contaminants are the primary methods for improving indoor air quality in most buildings. Indoor bio-aerosols may originate from outdoor air and indoor reservoirs. Outdoor bio-aerosols cannot easily migrate into large buildings with complex ventilation systems, however, certain categories of outdoor bio-aerosols (e.g. fungal spores) do serve as major sources for indoor bio-aerosols in naturally ventilated buildings, at specific periods of time [e.g., growing seasons for fungi. Major indoor sources for bioaerosols at residential homes include human occupants, pets, house dust, organic wastes, as well as the 
heating ventilation and air conditioning [HVAC] system (Wikipedia, 2012). To obtain quality air in buildings, vehicles, etc., air- conditioners, electric fans, doors/windows, etc., have been adopted as ventilation devices in many parts of Anambra state and Nigeria in general. Unfortunately these devices appear to be contaminated by microorganisms with time, as indicated by presence of biofilms on air-conditioners in some places. Some of the microbial contaminants seem to be of respiratory health significance hence, they serve as index reservoir and source of periodic infection of occupants of buildings and vehicles. Relationship of asthma to indoor environment and occurrence of asthma among school employees were reported (Smedje, Norback, Wessen and Edling 1996). Bacterial, actinomycetal and fungal contamination in the humidifier components of air-conditioning systems have been reported to induce bronchial disease (Spendlove and Fannin 1983). Air conditioners (ACs) also produce much dew and humid condition within the unit during operation, thus supporting the growth, multiplication and dispersal of various microbes.

Human respiratory diseases resulting from poor air quality occupy a prominent position in the hierarchy of communicable diseases in recent times. Among the dreaded human respiratory tract bacterial disease found in air-conditioners is Legionellae disease. This bacterium caused an explosive common source outbreak of pneumonia, which affected 182 persons attending the annual convention of the American legion in Philadelphia. Twenty-nine of them died. Following the above incidence, a non-pneumonia form oflegionellosis was subsequently detected by the screening of stored sera from an outbreak of respiratory tract illness, which had affected 90\% of the staff of the health department in Pontiac, Michigan (Glick 1978).

Epidemiological findings from recorded epidemics of Leionnaires' disease, suggest that the disease is spread by the air-borne route, from a common source (Eickhoff 1979). Several epidemics of legionellosis have been associated with contaminated air-conditioning towers (Dondero and Jr. 1980). Iluminado, Livelo, Ofelia, Monzon, Mediadora, Saniel and Keizo (1988) documented ubiquitos nature of Legionellae, however, they acknowledge that no local studies demonstrated the presence of Legionellae in the Philippines. The on going potential of air-conditioners and cooling towers in contributing to severe respiratory tract diseases was demonstrated by the Melbourne Aquarium outbreak in 2000. One hundred and twenty-five cases of Legionnaires disease and 4 deaths were reported (Greig, Carnie, Tallis, Ryon, Tan, Gordon, Zwolak, Legdon-guest, and Hart 2004). Thomas, Harrera-Rimann, Blanc and Greub (2006) reported that the types of microorganisms found within cooling towers are diverse and include bacteria, algae, fungi, protozoa and viruses. The majority of organisms they isolated were heterotrophs and required organic carbon as nutrient and energy source. Legionellae are commonly isolated from cooling towers and presents significant implications for public health by their potential to cause disease (Fields, Benson and Besser 2002).

In November 2008, a chief executive of an insurance company in Anambra state of Nigeria, reported to a clinic with a health condition that defied treatment for over 5 years. He presented with chronic pneumonia, cough, headache, fever and malaise. He also had neurological disorder, gastro-intestinal infection, with blood in stool, severe anemia, chest pain and respiratory distress. His HIV/AIDS status was negative. A medical laboratory diagnosis revealed respiratory mycosis, with heavy growth of Candida albicans in his sputum. He also had numerousEntamoebahistolytica in his stool (amoebiasis). He was then treated with fluconazole, metronidazole, blood builder and anagestics which resolved his ailment within 14 days. The patient admitted he was addicted to the use of air- conditioners in his house, car and office for over 25 years, before his terrible illness ensued (Personal communication 2008). In recent times in Nigeria, the global warming and improvement in people's life style have resulted in increasing use of air-conditioners and other ventilation devices. Parallel with these are increasing cases of pyrexia of unknown origin (PUO), pneumonia, allergy and other respiratory tract diseases, which often resist routine treatment. Some of these are speculated to have resulted from the use of ventilation devices, poor air quality and uncontrolled exposure to cold. Recent cases of pneumonia and other air-borne diseases, often associated to use of air-conditioners and other ventilation devices reported globally, necessitated the study. To the best of researcher's knowledge, this type of study has not been carried out in this part of the world. Hence, the study was carried out to determine the 
microbial control efficiency of air-conditioners and other ventilation devices like electric fans, doors and windows as means of improving future air quality in Anambra State of Nigeria and globally.

\section{Specific Objectives}

1. To determine the prevalence of Legionella species and other bacteria, in air- conditioners water samples from selected banks, hospitals and hotels in Anambra State.

2. To determine the prevalence of bacteria on surfaces of air conditioners vents, electric fans blades and doors/windows panels and frames in banks in Anambra State.

\section{Research Hypotheses}

The following null hypotheses guided the study.

1. There is no statistical significant difference in bacterial isolates associated with air-conditioners water samples from banks, hospitals and hotels in Anambra state.

2. There is no statistical significant difference in bacterial isolates associated with air-conditioners vents, electric fans blades and doors/windows frames in banks in Anambra state.

\section{Methodology}

This study adopted experimental techniques to evaluate the microbial efficiency of air-conditioners and other ventilation devices like electric fans and doors and windows as means of improving future air quality in Anambra State in particular and Nigeria at large.

Proportionate stratified random sampling technique was used to select a sample size of 150, (i.e. 45 banks, 61 hospitals and 44 hotels) from a population of 157 banks, 214 hospitals and 155 hotels in the 21 Local Government Areas (LGAs) in the state. The study started from February 2010 to July 2011. This accommodated the dry season/harmattan and raining season/wet period of the year in Anambra State.

Samples collection was carried out as follows:

a. Four hundred $(400) \mathrm{ml}$ of water samples were aseptically collected from water draining hoses of active air-conditioners water chambers from the sampled institutions (45 air-conditioners (ACs) in 45 banks, 61 ACs in 61 hospitals and 44 ACs in 44 hotels), from the 21 LGAs in Anambra state, see table 1.

b. Sterile wet swab sticks were used to collect swab samples from surfaces of 45 air-conditioners vents in 45 banks using ACs. Similarly 45 swab samples were collected from 45 electric fans blades from 45 banks using electric fans as ventilation devices.

c. The same number of samples (45) were collected from surfaces of doors/windows from banks using open doors/windows as ventilation devices, see table 2.

Isolation of Legionella species from A/Cs water samples.

Heat treatment technique was used in this exercise to isolate L. species from A/Cs water samples. The procedure was quite simple, inexpensive and does not require sophisticated equipment (Iluminado et al. 1988). The media used included Modified Wadosky-Yee (MWY) agar medium, Buffered Charcoal Yeast Extract (BCYE)-alpha medium and blood agar. Both MWY and BCYE-alpha medium contain L-cysteine and ferric pyrophosphate. MWY also contain Glycine which enhances the growth of environmental Legionella organisms and some antibiotics which inhibit the growth of other bacteria. The medium requires a strict PH of 6.9_+.05 to permit the growth of Legionellae (Wadosky, Wolford, McNamara and Yee 1985). Water 
samples from A/Cs discharge hoses were centrifuged at $4000 \mathrm{rpm}$ for $30 \mathrm{mins}$. The supernatants were discarded and $10 \mathrm{ml}$ of the sediment saved in each case. One (1) $\mathrm{ml}$ of the sediment was subjected to heat treatment at $50^{\circ} \mathrm{C}$ for 30 mins. The remaining $9 \mathrm{ml}$ were stored at $20^{\circ} \mathrm{C}$ for possible use later. Fifty (50) microliters of the heated water samples were inoculated onto BCYE $\alpha$ - agar mixed with MWY Legionella selective supplement IV sterile medium. The plates were incubated at $37^{\circ} \mathrm{C}$ under humidified air for 3-4 days. Bacteria colonies observed after incubation were further sub-inoculated on BCYE $\alpha$ - agar plates and fresh blood agar plates and incubated for further 3-4 days at $37^{\circ} \mathrm{C}$. Re-inoculated isolates which failed to grow on blood agar, but grew on BCYE $\alpha$-agar, were presumptive for Legionella species. These should appear as a glistening, grey-white, convex and speckled colony, which is 1-4 mm in diameter. A few strains have a slight blue colour and stains poorly Gram negative. A confirmation is achieved using biochemical tests and serotyping.

Seeding of blood agar plates for bacterial isolates.

The remaining portions $(9 \mathrm{ml})$ of ACs centrifuged water samples deposit were shaken slightly to suspend the deposits. Fifty (50) microliter of each sample was used to seed the surface of carefully labeled sterile blood agar plates. The plates were incubated at $37^{\circ} \mathrm{C}$ under humidified air for $48 \mathrm{hrs}$ to permit growth of bacteria that may be found in air-conditioners water chambers. Significant bacterial colonies on blood agar plates were Gram stained. The isolates were further subjected to other bacteriological and biochemical tests for identification.

\section{Culture of swab samples}

Samples collected with sterile wet swab sticks from surfaces of A/Cs vents, electric fans blades and doors/windows frames were carefully smeared on surfaces of properly labeled BCYE $\alpha$ - agar/MWY selective medium plates and blood agar plates. The plates were incubated at $37^{\circ} \mathrm{C}$ under humidified condition for 3 to 4 days for Legionella species and 1 to 2 days for other bacterial growth. Observed bacterial colonies were subjected to further bacteriological and biochemical tests for identification using standard procedure.

\section{Results}

Table 1. Prevalence of bacterial isolates associated with air-conditioners' water samples in banks, hospitals and hotels in anambra state.

\begin{tabular}{|c|c|c|c|c|c|c|c|c|c|}
\hline \multirow[b]{2}{*}{ L.G. A. } & \multicolumn{3}{|c|}{ BANKS } & \multicolumn{3}{|c|}{ HOSPITALS } & \multicolumn{3}{|c|}{ HOTELS } \\
\hline & $\begin{array}{c}\text { No. of } \\
\text { A/C } \\
\text { examine } \\
\text { d }\end{array}$ & $\begin{array}{c}\text { +ve } \\
\text { samples } \\
/ \\
(\%)\end{array}$ & $\begin{array}{c}\text { Bacteria } \\
\text { isolated } \\
\text { predominantly }\end{array}$ & $\begin{array}{c}\text { No.of } \\
\text { A/C } \\
\text { examined }\end{array}$ & $\begin{array}{c}\text { No. of +ve } \\
\text { samples / } \\
(\%)\end{array}$ & $\begin{array}{c}\text { Bacteria } \\
\text { isolated } \\
\text { predominantly }\end{array}$ & $\begin{array}{c}\text { No. of } \\
\text { A/C } \\
\text { examined }\end{array}$ & $\begin{array}{c}\text { No. of }+ \text { ve } \\
\text { samples } \\
/(\%)\end{array}$ & $\begin{array}{c}\text { Bacteria } \\
\text { isolated } \\
\text { predominantl } \\
\text { y }\end{array}$ \\
\hline Aguata & 3 & $2(1.3 \%)$ & M.luteus & 1 & $1(1.6 \%)$ & A.globiformis & 2 & $2(4.5 \%)$ & A.globiformis \\
\hline $\begin{array}{c}\text { Anambra } \\
\text { east }\end{array}$ & 1 & $1(0.7 \%)$ & S.epidemidis & 1 & $1(1.6 \%)$ & S.epidemidis & 0 & $0(0.0 \%)$ & ---- \\
\hline $\begin{array}{c}\text { Anambra } \\
\text { west }\end{array}$ & 0 & $0(0.0 \%)$ & ----- & 0 & $0(0.0 \%)$ & $\ldots \ldots$ & 0 & $0(0.0 \%)$ & ---- \\
\hline
\end{tabular}




\begin{tabular}{|c|c|c|c|c|c|c|c|c|c|}
\hline Anaocha & 3 & $3(2.0 \%)$ & M.luteus & 2 & $2(3.3 \%)$ & S.epidemidis & 1 & $1(2.3 \%)$ & M.luteus \\
\hline $\begin{array}{l}\text { Awka } \\
\text { north }\end{array}$ & 1 & $1(2.2 \%)$ & A.globiformis & 1 & $1(1.6 \%)$ & S.epidemidis & 0 & $0(0.0 \%)$ & …- \\
\hline $\begin{array}{l}\text { Awka } \\
\text { south }\end{array}$ & 6 & $5(11.1 \%)$ & M.luteus & 5 & $5(8.2 \%)$ & M.luteus & 10 & $7(15.9 \%)$ & M.luteus \\
\hline $\begin{array}{c}\text { Ayamelu } \\
\mathrm{m}\end{array}$ & 1 & $1(2.2 \%)$ & M.luteus & 0 & $0(0.0 \%)$ & $\ldots \ldots$ & 0 & $0(0.0 \%)$ & --- \\
\hline $\begin{array}{c}\text { Dunukofi } \\
\mathrm{a}\end{array}$ & 1 & $1(2.2 \%)$ & M.luteus & 1 & $1(1.6 \%)$ & A.globiformis & 1 & $1(2.3 \%)$ & M.luteus \\
\hline Ekwusigo & 1 & $1(2.2 \%)$ & A.globiformis & 1 & $1(1.6 \%)$ & A.globiformis & 0 & $0(0.0 \%)$ & --- \\
\hline $\begin{array}{c}\text { Idemili } \\
\text { north }\end{array}$ & 4 & $3(6.7 \%)$ & M.luteus & 6 & $5(8.2 \%)$ & S.epidemidis & 8 & $3(6.8 \%)$ & A .globiformis \\
\hline $\begin{array}{c}\text { Idemili } \\
\text { south }\end{array}$ & 2 & $2(4.4 \%)$ & M.luteus & 5 & $5(8.2 \%)$ & S.epidemidis & 2 & $2(4.5 \%)$ & Aglobiformis \\
\hline Ihiala & 2 & $2(4.4 \%)$ & A.globiformis & 4 & $4(6.6 \%)$ & S.aureus & 2 & $2(4.5 \%)$ & S.epidemidis \\
\hline Njikoka & 2 & $2(4.4 \%)$ & M.luteus & 4 & $4(6.6 \%)$ & S.epidemidis & 2 & $1(2.3 \%)$ & A.globiformis \\
\hline $\begin{array}{c}\text { Nnewi } \\
\text { north }\end{array}$ & 3 & $3(6.7 \%)$ & A.globiformis & 6 & $5(8.2 \%)$ & S.aureus & 3 & $3(6.8 \%)$ & S.epidemidis \\
\hline $\begin{array}{c}\text { Nnewi } \\
\text { south }\end{array}$ & 1 & $1(2.2 \%)$ & Mluteus & 1 & $1(1.6 \%)$ & S.epidemidis & 0 & $0(0.0 \%)$ & ---- \\
\hline Ogbaru & 4 & $3(6.7 \%)$ & M.luteus & 1 & $1(1.6 \%)$ & M.luteus & 2 & $2(4.5 \%)$ & S.epidemidis \\
\hline $\begin{array}{c}\text { Onitshan } \\
\text { orth }\end{array}$ & 6 & $4(8.9 \%)$ & A.globiformis & 15 & $11(18.0 \%)$ & A.globiformis & 8 & $7(15.9 \%$ & M.luteus \\
\hline $\begin{array}{c}\text { Onitsha } \\
\text { south }\end{array}$ & 0 & $0(0.0 \%)$ & ---- & 4 & $3(4.9 \%)$ & A.globiformis & 3 & $2(4.5 \%)$ & S.epidemidis \\
\hline $\begin{array}{c}\text { Orumba } \\
\text { north }\end{array}$ & 2 & $2(4.4 \%)$ & M.luteus & 1 & $1(1.6 \%)$ & M.luteus & 0 & $0(0.0 \%)$ & ---- \\
\hline $\begin{array}{c}\text { Orumba } \\
\text { south }\end{array}$ & 1 & $1(2.2 \%)$ & M.luteus & 1 & $1(1.6 \%)$ & M.luteus & 0 & $0(0.0 \%)$ & ---- \\
\hline Oyi & 1 & $1(2.2 \%)$ & S.epidemidis & 1 & $1(1.6 \%)$ & S.aureus & 0 & $0(0 . .0 \%)$ & $-\cdots$ \\
\hline Total & 45 & $39(26.0 \%)$ & & 61 & $54(88.5 \%)$ & & 44 & $33(72.7 \%)$ & \\
\hline
\end{tabular}

Table 1 showed 4 species of bacteria predominantly and frequently isolated in this study. A total of 126 bacterial isolates were recovered from 150 water samples examined in (45) banks, (61) hospitals and (44) hotels in the 21 LGAs in Anambra state. Isolates from banks was 39(26.0\%), hospitals 54(36.0\%) and hotels 33(22.0\%). Pooled bacterial isolates showed M. luteus was isolated highest 50(39.7\%) and was prevalent in 12 of the 21 LGAs. It was followed by A. globiformis 36(28.6\%) wish was prevalent in 10 LGAs. S. epidemidis 30(23.8\%) was also prevalent in 10 LGAs while S. aureuswas least isolated 10(7.9\%) aand was observed in 3 LGAs. Prevalent bacteria isolates per Institution analysis showed that $A$. globiformis was isolated highest 11(8.7\%) in hospitals air-conditioners water samples in Onitsha north LGA. The results subjected to statistical analysis revealed that Calc F-ratio value of 0.10 was $<3.11$ table value at p $0.05 \mathrm{df} 2 / 60$. Therefore null hypothesis of no significant statistical difference in bacterial isolates in air-conditioners water samples from banks, hospitals and hotels in Anambra state was accepted.

Table 2. Prevalence of bacterial isolates from air-conditioners' vents, electric fan blades and doors/window surfaces in banks in anambra state. 


\begin{tabular}{|c|c|c|c|c|c|c|c|c|c|}
\hline \multirow[b]{2}{*}{ L G. A. } & \multicolumn{3}{|c|}{ Air-conditioners vent } & \multicolumn{3}{|c|}{ Electric fan blade } & \multicolumn{3}{|c|}{ Doors/windows surface } \\
\hline & $\begin{array}{c}\text { No. } \\
\text { sampled }\end{array}$ & $\begin{array}{l}(\%) \\
+ \text { ve }\end{array}$ & Bacteria isolated & $\begin{array}{c}\text { No. } \\
\text { sampled }\end{array}$ & $\begin{array}{l}(\%) \\
+ \text { ve }\end{array}$ & Bacteria isolated & $\begin{array}{c}\text { No. } \\
\text { sampled }\end{array}$ & $\begin{array}{l}(\%) \\
+ \text { ve }\end{array}$ & $\begin{array}{l}\text { Bacteria } \\
\text { isolated }\end{array}$ \\
\hline Aguata & 3 & $3(2.2 \%)$ & S.epidemidis & 3 & $2(1.5 \%)$ & S.aureus & 3 & $1(0.7 \%)$ & S.aureus \\
\hline $\begin{array}{c}\text { Anambra } \\
\text { east }\end{array}$ & 1 & $1(0.7 \%)$ & A.globiformis & 1 & $1(0.7 \%)$ & A.globiformis & 1 & $1(0.7 \%)$ & A.globiformis \\
\hline $\begin{array}{c}\text { Anambra } \\
\text { west }\end{array}$ & 0 & $0(0.0 \%)$ & .. & 0 & $0(0.0 \%)$ & & $\mathbf{0}$ & $0(0.0 \%)$ & \\
\hline Anaocha & 3 & $3(2.2 \%)$ & M.luteus & 3 & $2(1.5 \%)$ & M.luteus & 3 & $2(1.5 \%)$ & M.luteus \\
\hline $\begin{array}{l}\text { Awka } \\
\text { north }\end{array}$ & 1 & $1(0.7 \%)$ & M.luteus & 1 & $1(0.7 \%)$ & M.luteus & 1 & $1(0.7 \%)$ & M.luteus \\
\hline $\begin{array}{l}\text { Awka } \\
\text { south }\end{array}$ & 6 & $4(2.9 \%)$ & A.globiformis & 6 & $3(2.2 \%)$ & A.globiformis & 6 & $2(1.5 \%)$ & A.globiformis \\
\hline Ayamelum & 1 & $1(0.7 \%)$ & M.luteus & 1 & $1(0.7 \%)$ & M.luteus & 1 & $0(0.0 \%)$ & \\
\hline Dunukofia & 1 & $1(0.7 \%)$ & A.globiformis & 1 & $1(0.7 \%)$ & A.globiformis & 1 & $1(0.7 \%)$ & A.globiformis \\
\hline Ekwusigo & 1 & $1(0.7 \%)$ & S.epidemidis & 1 & $1(0.7 \%)$ & S.epidemidis & 1 & $0(0.0 \%)$ & \\
\hline $\begin{array}{c}\text { Idemili } \\
\text { north }\end{array}$ & 4 & $3(2.2 \%)$ & A.globiformis & 4 & $2(1.5 \%)$ & S.aureus & 4 & $1(0.7 \%)$ & S.aureus \\
\hline $\begin{array}{l}\text { Idemili } \\
\text { south }\end{array}$ & 2 & $1(0.7 \%)$ & A.globiformis & 2 & $1(0.7 \%)$ & A.globiformis & 2 & $2(1.5 \%)$ & A.globiformis \\
\hline Ihiala & 2 & $1(0.7 \%)$ & A.globiformis & 2 & $1(0.7 \%)$ & A.globiformis & 2 & $1(0.7 \%)$ & $\begin{array}{c}A \\
\text { globiformis }\end{array}$ \\
\hline Njikoka & 2 & $2(1.7 \%)$ & M.luteus & 2 & $2(1.5 \%)$ & M.luteus & 2 & $2(1.5 \%)$ & M.luteus \\
\hline $\begin{array}{c}\text { Nnewi } \\
\text { north }\end{array}$ & 3 & $3(2.2 \%)$ & M.luteus & 3 & $2(1.5 \%)$ & S.epidemidis & 3 & $2(1.5 \%)$ & $\begin{array}{c}\text { S.epidemid } \\
\text { is }\end{array}$ \\
\hline $\begin{array}{c}\text { Nnewi } \\
\text { south }\end{array}$ & 1 & $1(0.7 \%)$ & S.epidemidis & 1 & $1(0.7 \%)$ & S.epidemidis & 1 & $1(0.7 \%)$ & \begin{tabular}{|c}
$\begin{array}{c}\text { S.epidemid } \\
\text { is }\end{array}$ \\
\end{tabular} \\
\hline Ogbaru & 4 & $3(2.2 \%)$ & S.epidemidis & 4 & $2(1.5 \%)$ & S.aureus & 4 & $1(0.7 \%)$ & S.aureus \\
\hline $\begin{array}{c}\text { Onitsha } \\
\text { north }\end{array}$ & 6 & $4(2.9 \%)$ & A.globiformis & 6 & $2(1.5 \%)$ & A.globiformis & 6 & $3(2.2 \%)$ & $\begin{array}{c}\text { A.globifor } \\
\text { mis }\end{array}$ \\
\hline $\begin{array}{l}\text { Onitsha } \\
\text { south }\end{array}$ & 0 & $0(0.0 \%)$ & ............ & 0 & $0(0.0 \%)$ & n........... & 0 & $0(0.0 \%)$ & \\
\hline $\begin{array}{c}\text { Orumba } \\
\text { north }\end{array}$ & 2 & $1(0.7 \%)$ & A.globiformis & 2 & $1(0.7 \%)$ & M.luteus & 2 & $1(0.7 \%)$ & M.luteus \\
\hline $\begin{array}{c}\text { Orumba } \\
\text { south }\end{array}$ & 1 & $1(0.7 \%)$ & M.luteus & 1 & $1(0.7 \%)$ & M.luteus & 1 & $1(0.7 \%)$ & M.luteus \\
\hline Oyi & 1 & $1(0.7 \%)$ & M.luteus & 1 & $1(0.7 \%)$ & M.luteus & 1 & $1(0.7 \%)$ & M.luteus \\
\hline Total & 45 & $36(26.7 \%)$ & & 45 & $\begin{array}{c}28(2 \mathrm{O} .7 \\
\%)\end{array}$ & & 45 & $\begin{array}{c}24(17.8 \\
\%)\end{array}$ & \\
\hline
\end{tabular}

Table 2 showed 4 predominant and frequent bacterial species isolated from surfaces of 3 commonly utilized ventilation devices in the state. A total of 88 bacterial isolates were made from 135 swab samples collected from surfaces of 45 air-conditioners vents, 45 electric fans blades and 45 doors/windows frames in banks in the state. The result showed that air-conditioners' vents had the highest number of bacterial isolates $36(26.7 \%)$, followed by electric fans blades 28(20.7\%). The least number of isolates came from doors/windows frames/panels 24(17.8\%).Pooled bacterial isolates in the 21 LGAs showed that A. globiformis had the highest number of isolates 35(39.8\%) in 8 of the 21 LGAs, followed by M. luteus 29(33.0\%) also prevalent in 8 LGAs, S. epidemidis $15(17.0 \%)$ was prevalent in 5 LGAs while S. aureus was least isolated 
9(10.2\%) and was prevalent in only 3 of the LGAs. Ventilation device per LGA analysis indicated that Onitsha north LGA had highest number of isolates 4(2.8\%) which came from banks using A/Cs as ventilation device. Statistical analysis showed that $\mathrm{F}$ Calc. value 1,51 was $<3.11$ critical value $\mathrm{p} 0.05$ and $\mathrm{df}$ $2 / 45$. Therefore the null hypotheses of no significant statistical difference in bacterial isolates from surfaces of $\mathrm{A} / \mathrm{Cs}, \mathrm{EFs}$ and $\mathrm{D} / \mathrm{W}$ s in banks using such ventilation devices was accepted

\section{Discussion}

Four bacterial species were predominantly and frequently isolated from various ventilation devices, which were examined in this study. The ventilation devices which include air-conditioners, electric fans and open doors/windows are used in various establishments as a means of control and enhancement of air quality. They provide conducive indoor environment for occupants of buildings and vehicles when they are in use. Unfortunately, the bacterial isolates which include Micrococcus luteus, Arthrobacter globiformis both of which belong to the family of actinomycetes, Staphylococcus aureus and S.epidemidis were discovered as serious contaminants of the various ventilation devices. The isolates co-exist as habitants of the ventilation devices utilizing available nutrients circulating in environmental aerosols for survival . They also take advantage of the suitable temperature and humidity to thrive, leading to formation of biofilms when undisturbed by surface cleaning, over a length of time. The biofilms remain as hidden source of continuous dosing and infection of occupants of apartments where they exist, as they get detached and circulate in bioaerosols. The observation agree with the findings of (Sungur et al. 2005) and (Thomas et al. 2006) who reported that the types of microorganisms found within cooling towers are diverse and include bacteria, algae, fungi, protozoa and viruses. Majority of the organisms they isolated were heterotrophs and required organic carbon as nutrient and energy source.

Pneumonia causing bacterium, Legionella pneumophila reported by some researchers as commonly found in air-conditioners was not isolated in this study. This could be as a result of variation in environmental conditions and unavailability of their nutrient requirement since the bacterium is fastidious in its growth requirement. However, further studies are needed to confirmed the complete absence of this respiratory health significant bacterium from other environmental sources in this state in particular and Nigeria in general. The findings of this study therefore did not agree with the results of (Iluminado et al. 1988) who documented the ubiquitous nature of Legionellae in Metro Manila, though they acknowledged the fact that no local studies reported the presence of the organism in Philippines.

The prevalence of other bacteria isolates namely Micrococcus luteus, Arthrobacter globiformis, Staphylococcus aureus and Staphylococcus epidemidis in the 3 institutions (banks, hospitals and hotels) see table 1, was an indication of the ubiquitous nature of the isolates. Statistical analysis of the results revealed that Calc. F-value of 0.10 was $<3.11$ table value at p $0.05 \mathrm{df} 2 / 60$. Therefore, the null hypotheses of no significant statistical difference in bacterial isolates in air- conditioners water samples from banks, hospitals and hotel in Anambra state was accepted. The institutions/ LGAs analysis showed that $A$. globiformis was isolated highest 11(8.7\%) in hospital air-conditioners in Onitsha north LGA. Their prevalence in the various institutions and LGAs, is an indication of their air-borne status, and the ability to access and survive in air-conditioners. From this vantage position, they multiply, get into the indoor circulation causing poor air quality and poses a danger to occupants of the apartments.

The prevalence of bacterial isolates from surfaces of A/Cs vents, E/Fs blades and D/Ws in banks in Anambra state showed that A/Cs vents had the highest bacterial isolates 36(26.7\%), followed by E/Es blades $28(20.7 \%)$. The least number of isolates $24(17.8 \%)$ was made from D/Ws. Statistical analysis of the result showed that F-Calc. value of 11.52 was $>3.11$ critical value at p 0.05 and $\mathrm{df} 2 / 60$. Therefore the alternative hypotheses of there was significant statistical difference in bacterial isolates from the examined surfaces was accepted. LGAs/Ventilation devices analysis showed that Onitsha north LGA had the highest number of 
bacterial isolates $4(2.8 \%)$ which was obtained from $\mathrm{A} / \mathrm{Cs}$ vents. The various observations above indicated that $\mathrm{A} / \mathrm{Cs}$ has the highest propensity to harbor and disseminate microbes when compared with other ventilation devices which could be used to secure future air quality.

\section{Conclusion}

Ventilation devices especially air-conditioners, play important role in filtering and circulating quality air and providing conducive environment inside dwellings, offices and other cabins as in cars, ships, aero planes etc. This study discovered that air-conditioners ranked highest above other ventilation devices, in harboring various kinds of microbes, which they may introduce and circulate periodically in indoor micro-environment in some apartments, affecting the occupants health wise. Such appliances are therefore not $100 \%$ efficient in their present state as means of achieving future air quality.

\section{Recommendations}

1. Engineers should use materials that are not habitable by microorganisms in construction of various ventilation devices to ensure the safety of the user.

2. There should be monthly cleaning of air-conditioners' vents and their other accessible components. Chemical disinfection with bleach of $3 \%$ hydrogen peroxide solution is effective for short time measure. In recent years, fungicides such as Tiabendazole (TBZ) have been applied to the airconditioners' filters. The effect has been shown not to continue for more than two years. (Hamada et al. 1993).In a similar manner electric fans blades and doors/windoors surfaces should be cleaned and disifected periodically.

3. There should be quarterly or biannual microbiological examination of air-conditioners and surfaces of other ventilation devices for pathogens or opportunistic microorganisms of respiratory health significance.

4. Air-conditioners and other ventilation devices should not be located in positions where external pollutants e.g. sewage, poultry farms, ponds, abattoirs, industrial wastes, toxic wastes etc. could take advantage of them to constitute a source of danger to users.

5. Air-conditioners, electric fans and open doors/windoors should be positioned in such a way that strong air current coming from them, shall not gain direct entry into the inner nostrils of users.

\section{References}

Brundage, J.F. and Scott, R. (1988). Building associated risk of febrile acute respiratory diseasein army trainees. Journal of the American Medical Association. 259; 2108-12.

Burge, H. A. (1990). Bioaerosols prevalence and health effects in the indoor environment.Journal of Allergy and Clinical Immunology. 86; 687-704.

Fields, B. S., Benson, R. F. \&Besser, R.E.(2000). Legionella and legionnaires'disease 25 years of investigation.Clinical Microbiology Reviews 15(3) 506-526.

Greig, J. E., Carnie, J. A., Tallis, G.F.,Ryan, J.N.,Tan,g.G.A., Gordon, I.R.,Zwolak, B. Leydon, J.A.,Guest,C.S. \& Hart ,W,J. (2004). An outbreak of Legionnaires' disease at Melbourne Aquarium. Investigation and case control studies. Medical Journal of Australia.180, 566-572.

Gick, T. H. (1978). Pontiac Fever, an epidemic of unknown etiology in health department. Journal of Clinical \& Epidemiological Aspects. 107, 149-160.

Iluminado, P., Livelo, M.T., Ofelia, T., Monzon, M. D.,Mediadora, C., Saniel, M. D. \&Keizo-Yamagushi, M. D. (2008).Isolation of Legionella from the environment.Retrieved on 4th January, 2011 from

http//www.emedicine.com/med/topic1273.htm. 
Sungur, E.I. \&Coluk, A. (2OO5). Characterization of sulphate reducing bacteria isolated from cooling towers.Environmental Monitoring and Accessment. 104, 211-219.

Thomas, V., Herrera-Rimann, K., Blanc, D. S.\&Greub, G. (2006). Biodiversity of Amoeba and Amoeba resisting bacteria in a hospital water network. Applied and Environmentl Microbiology. 39(2): 256-265. 
